\title{
ANALISIS MENGENAI PENGARUH POLITIK TERHADAP KEHIDUPAN DI KAMPUNG YEFLIO DISTRIK MAYAMUK KABUPATEN SORONG
}

\author{
Aswad Muhdar \\ Universitas Muhammadiyah Sorong \\ aswadmuhdar@gmail.com
}

\begin{abstract}
Abstrak
Kebebasan berotonomi di kampung ada ruang gerak politik yang diberikan oleh pemerintah lewat lembaga politik lembaga politik menjadi saluran komunikasi, dalam menyampaikan kehendak dan aspirasi masyarakat kampung dalam kehidupan berpolitik. Tetapi kelembagaan politik itu juga hanya terbatas pada mereka yang dianggap memiliki kepentingan, sedangkan secara nyata dalam partisipasi politik adalah sebagai besar masyarakat harus turut mengambil bagian dalam proses pendewasaan politik. Maka jalan satu-satunya dalam memberikan pemahaman dan wawasan bagi msyarakat di kampung adalah melalui pemahaman terhadap pengaruh politik dalam kehidupan masyarakat. Jenis penelitian menggunakan metode kualitatif yang bersifat deskriptif dengan menggunakan tehnik pengumpulan data melalui pengamatan, wawancara, dan dokumentasi. Berdasarkan hasil penelitian dapat ditarik kesimpulan : Bahwa Analisis mengenai pengaruh politik terhadap kehidupan masyarakat di kampong Yeflio Distrik Mayamuk Kabupaten Sorong masih perlu meningkatkan pengaruh politik dan sosialisasi masyarakat tentang tujuan diadakannya politik agar masyarakat kampong Yeflio Distrik Mayamuk Kabupaten Sorong bisa menerima calon kandidat mereka tanpa terjadi anarkis karena calon yang lainnya gagal dalam persaingan, perlunya peningkatan sumber daya manusia dengan memberikan pengiriman tugas belajar, pelatihan dan kursus. Sesuai dengan apa yang diharapkan oleh masyarakat yang belum mencapai hasil yang optimal dikarenakan pengaruh politik sumber daya manusia masih kurang dan perlu di tingkatkan lagi.
\end{abstract}

Kata Kunci: Pengaruh Politik dan Kehidupan

\begin{abstract}
Freedom of autonomy in the village there is political space provided by the government through political institutions, political institutions become a channel of communication, in conveying the will and aspirations of the village community in political life. However, political institutions are also limited to those who are considered to have an interest, while in reality political participation is that a large part of the community must take part in the process of political maturation. So the only way to provide understanding and insight for the community in the village is through an understanding of the influence of politics in people's lives. This type of research uses descriptive qualitative methods using data collection techniques through observation, interviews, and documentation. Based on the results of the study, it can be concluded: That the analysis of political influence on people's lives in Yeflio village, Mayamuk District, Sorong Regency still needs to increase political influence and socialization of the community about the purpose of holding politics so that the Yeflio village community, Mayamuk District, Sorong Regency can accept their candidates without anarchy. because the other candidates failed in the competition, the need to increase human resources by providing delivery of learning assignments, training and courses. In accordance with what is expected by the community, which has not achieved optimal results because the political influence of human resources is still lacking and needs to be improved again.
\end{abstract}

Keywords: Political Influence and Life

JIA | Volume 9 | Nomor 2 | Edisi Agustus 2021 


\section{A. PENDAHULUAN}

Perkembangan dunia politik salah satunya disebabkan untuk kesejahteraan masyarakat. Meningkatnya golongan menengah ke atas dari segi financial, dan kepuasan masyarakat. Cikal bakal terbentuknya masyarakat politik dan pemerintahan di Indonesia jauh sebelum Negara ini terbentuk. Maka pengaruh politik terhadap kehidupan masyarakat dan telah menjadi institusi social sejenis desa, masyarakat adat dan lain sebagainya telah menjadi institusi sosial yang mempunyai posisi yang sangat penting dalam analisis mengenai pengaruh politik terhadap kehidupan masyarakat.

Pengaruh politik adalah pada dasarnya adalah jalan menuju proses pembaharuan bagi rakyat di kampung dalam kehidupan berpolitik. Di zaman orde baru ada banyak masalah yang muncul berkaitan dengan kepentingan pembangunan kampong dimana rakyat di kampong tidak diberi ruang dalam menyampaikan aspirasi politik. Berbagai pendekatan dilakukan untuk mendapatkan simpati masyarakat untuk mempengaruhi dan mengajak masyarakat dalam kehidupan politik,baik melalui peningkatan sarana dan prasarana, perkenalan bidang teknologi maupun dengan pengembangan sumber daya manusia.

Rakyat di kampung mulai diberi kebebasan untuk menyampaikan aspirasi politik lewat pemilu dimana hadirnya banyak partai politik rakyat di kampung diberi kebebasan untuk memilih partai politik berdasarkan kemauannya sendiri. Akibat dari kebebasan politik di kampong, telah terjadi suatu perubahan sikap, bahkan diantara mereka sering sekali muncul konflik secara internal baik antara keluarga maupun antara sesame rakyat di kampung. Ajang pertarungan politik dimana reformasi membawa angin segar bagi rakyat di kampung dalam berdemokrasi. Kekuasaan dan pengaruh kepala kampung mulai surut dan digantikan dengan rakyat yang bebas memilih aspirasi dan kepentingan politiknya.

Analisis mengenai pengaruh politik dianggap sebagai altenatif dalam merubah sikap dan perilaku masyarakat di kampung dalam berdemokrasi. Karena analisis mengenai pengaruh politik bukan saja dilakukan bagi masyarakat di kampong untuk ikut dalam kegiatan organisasi, ikut dalam pemilu, baik pemilu legislative maupun pemilu
Presiden maupun Bupati, ikut serta dalam pemilihan kepala kampong, tetapi lebih dari itu analisis mengenai pengaruh politik harus dapat dilakukan bagi masyarakat di kampong lewat transformasi pengetahuan, transformasi pemahaman terhadap politik, serta masyarakat di kampong mampu berkonsolidasi lewat penyampain aspirasi demi kepentingan pembangunan masyarakat di kampungnya.

Inilah harapan yang dapat dimaknai dari pentingnya analisis mengenai pengaruh politik terhadap kehidupan masyarakat di kampong,bukan sekedar direkrut, diorganisir dalam kelembagaan tetapi lebih dari itu masyarakat di kampong diberi tanggung besar dan kebebasan dalam memikul beban yang ditanggung oleh mereka sendiri demi kepentingan pembangunan masyarakat dikampungnya. Hal ini tidak kalah pentingnya analisis terhadap pengaruh politik bagi kehidupan masyarakat di kampong adalah mengatasi berbagai problema dengan ketidak berdayaan seperti malas, boros, pola hidup konsumtif, mementingkan diri sendiri, egois, apatis dengan kenyataan hidup yang ada dan lain-lainnya.

Analisis adalah aktivitas yang terdiri dari serangkaian kegiatan seperti, mengurai, membedakan, memilah sesuatu untuk dikelompokkan kembali menurut kriteria tertentu dan kemudian dicari kaitannya lalu ditafsirkan maknanya. Analisis dapat juga diartikan sebagai usaha dalam mengamati sesuatu secara mendetail dengan cara menguraikan komponen-komponen pembentuknya atau menyusun komponen tersebut untuk dikaji lebih lanjut.

Definisi ini merupakan rumusan umum tentang analisis. Menurut Sugiono (2015:335), Analisis adalah kegiatan untuk mencari pola, atau cara berfikir yang berkaitan dengan pengujian secara sistimatis terhadap sesuatu untuk menentukan bagian, hubungan antar bagian, serta hubungannya dengan keseluruhan. Menurut Satori dan Komaryah (2014: 200), Defenisi Analisis adalah usaha untuk mengurai suatu masalah menjadi bagian-bagian. Sehingga, susunan tersebut tampak jelas dan kemudian bisa ditangkap maknanya atau dimengerti duduk perkaranya.

Berdasarkan beberapa rumusan defenisi diatas, dapat disimpulkan bahwa analisis memiliki sedikitnya tiga fungsi dan tujuan utama. Namun secara spesifik, hal ini akan tergantung bagaimana proses 
penggunaan metode analisis, secara umum, berikut fungsi dan tujuannya.

Fungsi dan tujuan analisis untuk dapat mengumpulkan data-data yang terdapat pada suatu lingkungan tertentu. Analisis dapat diterapkan diberbagai jenis lingkungan dan juga keadaan. Analisis akan lebih optimal dipergunakan dalam keadaan kritis serta juga untuk keadaan yang membutuhkan strategi. Disebabkan karena analisis bisa mengetahui secara mendetail mengenai keadaan lingkungan saat ini.

Menurut Spradley (Sugiyono, 2015 : 335) mengatakan bahwa analisis adalah sebuah kegiatan untuk mencari suatu pola selain itu analisis merupakan cara berfikir yang berkaitan dengan pengujian secara sistimatis terhadap sesuatu untuk menentukan bagian, hubungan antar bagian dan hubungan dengan keseluruhan. Analisis adalah suatu usaha untuk mengurangi suatu masalah atau focus kajian menjadi bagianbagian (decomposition) sehingga susunan/tatanan bentuk sesuatu yang diurai itu tampak dengan jelas dan karenanya bisa secara lebih terang ditangkap maknanya atau lebih jernih dimengerti duduk perkaranya (Satori dan Komariyah, 2014:200)

Sementara itu, Nasution dalam Sugiyono (2015:334) melakukan analisis adalah pekerjaan sulit, memerlukan kerja keras. Tidak ada cara tertentu yang dapat diikuti untuk mengadakan analisis, sehingga setiap peneliti harus mencari sendiri metode yang dirasakan cocok dengan sifat penelitiannya. Analisis menurut pemikiran Eiradi (2006:7) adalah aktivitas yang memuat sejumlah kegiatan seperti mengurai, membedakan, memilah sesuatu untuk digolongkan dan dikelompokkan kembali menurut kriteria tertentu kemudian dicari kaitannya dan ditafsirkan maknanya.

Kemudian menurut Dwi Prastowo Darminto dan Rifka Julianty (2002:52) mengatakan bahwa analisis adalah sebagai penguraian suatu pokok atas berbagai bagiannya dan penelahan bagian itu sendiri, serta hubungan antar bagian untuk memperoleh pengertian yang tepat dan pemahaman arti keseluruhan. Miriam Budiardjo mengartikan politik yaitu bermacam-macam kegiatan dalam suatu system politik (atau Negara) yang menyangkut proses menentukan tujuantujuan dari system dan melaksanakan tujuan-tujuan itu.
Pengertian yang lebih komprehensif tentang politik dikemukakan Ramlan Subakti yaitu interaksi antara pemerintah dan masyarakat, dalam rangka proses pembuatan dan pelaksanaan keputusan yang mengikat tentang kebaikan bersama masyarakat yang tinggal dalam suatu wilayah tertentu (Cholisin dan Nasiwan, 2012:1).

Politik adalah kegiatan dalam sistem pembangunan Negara melalui pembagianpembagian kekuasaan atau pendapatan untuk mencapai tujuan yang telah disepakati. Dunia politik sangat berpengaruh terhadap kemajuan ekonomi suatu bangsa dan daerah Menurut pendapat Surbakti (2010:187) menjelaskan pendekatan psikologis social sama dengan penjelasan yang diberikan dalam model prilaku politik. Salah satu konsep psikologis social yang digunakan untuk menjelaskan prilaku untuk memiliki pada pemilihan umum berupa identitas partai.

Perilaku politik juga termasuk kegiatan masyarakat dalam proses meraih kekuasaan. Rumusan lain prilaku politik adalah semua prilaku manusia baik sebagai individual maupun masyarakat yang berkaitan dengan proses pembuatan kebijakan, konflik, kebaikan bersama, serta kekuasaan (Cholisin dan Nasiwan, 2012:144). Menurut Budi Winarno (2017:2), terdapat tiga pendekatan dalam studi politik. Pertama, pendekatan normative (normative aoorach). Pendekatan ini biasanya dipakai oleh ilmuwan politik yang tertarik mempelajari sejarah ide-ide politik dan sosiologi pengetahuan. Pendekatan normatif mewakili kecendrungan tradisional yang berawal sebelum filsafat di pisahkan dari politik. Ketiga, pendekatan prilaku (behavioral approach). Pendekatan ini dipengaruhi oleh psikologi.

Kekuatan politik merupakan gerakan yang dilakukan oleh suatu golongan dalam mencapai atau mempertahankan tujuannya, gerakan tersebutdapat berupa gerakan konservatif maupun gerakan progresif dengan menerapkan nilai-nilai liberalism (Hays 2011:122).

Istilah yang paling lazim dipakai untuk menyebut kesatuan-kesatuan hidup manusia, baik dalam tulisan ilmiah maupun bahasa sehari-hari adalah masyarakat. Menurut Soerjono Soekanto (1993:103), para ahli antropologi social biasanya mengartikan masyarakat sebagai wadah dari orang-orang buta huruf, mengadakan refroduksi sendiri, mempunyai adat istiadat, mempertahankan 
ketertiban, dengan menerapkan sanksi-sanksi sebagai sarana pengendalian social, dan yang mempunyai wilayah tempat tinggal yang khusus.

Sedangkan menurut Koentjaraningrat (2002:146), mendefenisikan mengenai masyarakat secara khusus yaitu kesatuan hidup manusia yang berinteraksi menurut suatu system adat istiadat tertentu yang bersifat kontinyu, dan yang terikat oleh suatu rasa identitas bersama kehidupan masyarakat itu saling mempengaruhi satu sama lain, dimana saling berhubungan tingkah laku dan perbuatan yang dilandasi oleh suatu kaidah dan siapa yang melanggarnya akan diberi sanksi sesuai dengan ketentuannya. Masyarakat adalah sekelompok individu atau orang yang saling tergantung satu sama lain dan hidup bersama dalam satu komunitas, dimana sebagian bessar interaksi adalah antara individu-individu yang berada dalam satu komunitas, dimana sebagian besar interaksi adalah antara individu-individu yang berada dalam kelompok tersebut.

Arti pemimpin adalah seorang pribadi yang memiliki kecakapan dan kelebihan, khususnya kecakapan atau kelebihan di satu bidang sehingga dia mampu mempengaruhi orang-orang lain untuk bersama-sama melakukan aktivitas-aktivitas tertentu demi mencapai satu atau beberapa tujuan, (Kartini Kartono, 1994:181).

Menurut Krit didalam bukunya Behavion at Work dikutip oleh Hick and Gullet (1984:493) menyatakan "Tanpa pemimpin suatu organisasi hanya merupakan campur aduknya manusia dan peralatan kepemimpinan merupakan kecakapan untuk menyalur orang-orang agar mengusahakan secara tegas tujuan dengan penuh semangat. Hal ini merupakan factor manusia yang mengikat suatu kelompok untuk bersamasama dan mendorong terhadap tujuan bersama.

Menurut Kartini Kartono (183:61), merumuskan tugas dan fungsi kepemimpinan yaitu memandu, menuntun, membimbing, membangun, memberikan motivasi kerja, mengemudikan organisasi, menjalani jaringan komunikasi yang baik, member supervise/pengawasan yang efesien, membawa para pengikutnya kepada sasaran yang ingin dituju sesuai dengan ketentuan waktu dan perencanaan.

\section{B. METODE PENELITIAN}

Penelitian ini dilakukan dengan menggunakan metode penelitian yang sesuai agar dapat menjawab permasalahan sesuai dengan hal itu maka jenis metode penelitian yang dipakai. Menurut Umar (2003:112), metode Kualitatif adalah riset yang diadakan untuk memperoleh fakta-fakta tentang gejalagejala atas permasalahan yang timbul. Sifat penelitian yang digunakan dalam ini adalah bersifat deskriptif-analitis. Deskriptif-Analitis merupakan metode yang dipakai untuk menggambarkan suatu kondisi atau keadaan yang sedang terjadi atau berlangsung yang tujuannya agar dapat member data seteliti mungkin mengenai obyek penelitian sehingga mampu menggali hal-hal yang bersifat ideal, kemudian dianalisis berdassarkan teori yang telah mapam. Dalam penelitian ini hal tersebut dilakukan dengan menguraikan mengenai analisis mengenai pengaruh politik terhadap kehidupan masyarakat di kampong Yeflio Distrik Mayamuk Kabupaten Sorong. Penelitian ini menggunakan analisis Kualitatif, yaitu dengan menggabungkan semua data yang diperoleh dari hasil penelitian di lapangan serta segala informasi yang diperoleh dari orang serta literatu-literatur yang ada, kemudian dilakukan analisa kualitatif berdasarkan penafsiran-penafsiran sesuai bukti yang ada juga menjawab permasalahan yang ada.

\section{HASIL DAN PENELITIAN}

Analisis Mengenai Pengaruh Politik Terhadap Kehidupan Masyarakat Di Kampung Yeflio Distrik Mayamuk Kabupaten Sorong. Realitas social yang terjadi di kampong Yeflio dalam kaitannya dengan pengaruh politik ataupun sejauh mana politik dapat mempengaruhi tingkah laku kehidupan social masyarakatnya masih sangat sulit diukur dengan takaran tertentu. Padahal, dalam menentukan peradaban suatu entitas social, perilaku public baik disadari maupun tidak disadari akan mengarah pada sikap politik tertentu. Dapat pula dikatakan bahwa politik merupakan suatu aktivitas intelektual yang sudah ada sejak lama.

Narasumber penulis salah satu staf Penasehat Noakfami yang penulis peroleh hasil wawancara (sorong oktober 2020) mengatakan bahwa: Analisis mengenai pengaruh politik terhadap kehidupan masyarakat di kampong Yeflio Distrik Mayamuk Kabupaten Sorong, Suatu 
pemerintah dapat dikatakan demokratis jika terdapat indokator penunjang utama yaitu keterwakilan rakyat dalam pemerintahan, partisipasi masyarakat dalam pemilihan wakil dalam lembaga politik dalam keikutsertaan dalam perencanaan pembangunan dan kontrol terhadap pemerintahan itu sendiri. Hal ini juga terlihat dalam pemerintahan di kampong Yeflio yang tercermin sebagai pelaksana pemerintahan, partisipasi masyarakat dan Badan Permusyawaratan Desa (BPD) sebagai badan legislasi.

Menurut narasumber penulis bagian Kasih Sayang Yosep Simiyang Penulis peroleh hasil wawancara (Sorong, Oktober 2020) mengatakan bahwa: pengaruh politik di kampong dalam setiap pengambilan keputusan untuk melaksanakan programprogram harus mementingkan seluruh kepentingan masyarakat kampong Yeflio. Kepala kampong adalah alat pemerintah, alat pemerintah daerah dan alat pemerintah desa yang memimpin penyelenggaraan pemerintahan kampong. Kepala kampong sebagai penyelenggara pemerintahan kampong memiliki tanggungjawab utama di bidang peningkatan pembangunan dan kehidupan masyarakat Yeflio Kabupaten Sorong.

Selanjutnya dikatakan kepada penulis Bagian Kasih Sayang Yosep Simiyang penulis peroleh hasil wawancara (Sorong, Oktober 2020) mengatakan bahwa Analisis Mengenai Pengaruh Politik di Kampung Yeflio perlu disadari bahwa pekerjaan kepala kampong bukanlah tanggung jawab kepala kampong saja, maka dari itu melimpahkan semua wewenangnya kepada semua tingkat pimpinan sampai ketingkat bawahan seperti kepala dusun dan lainnya.

Analisis Politik Terhadap Masyarakat Di Kampung Yeflio Distrik Mayamuk Kabupaten Sorong. Tindakan-tindakan dalam pengamanan terhadap masyarakat yang tidak mengarah pada konstitusi atau amanat bangsa, UUD 1945 serta Pancasila sudah dalam analisis politik terhadap masyarakat di kampong Yeflio Distrik Mayamuk Kabupaten Sorong, selayaknya sesegera mungkin mendapatkan perhatian yang serius oleh lembaga atau instansi-instansi penegak hokum untuk melaksanakan pemilihan kepala kampong atau distrik bisa berjalan sebagaimana yang diharapkan dan diinginkan untuk kehidupan masyarakat agar dapat hidup sejahtera dari pemimpin yang mereka pilih tindak berdasarkan amanat undangundang yang berlaku. Era reformasi ini memang tidak di pungkiri bahwa pemilihan umum kepala daerah pada era reformasi memang seringkali menimbulkan pahampaham yang berbeda bahkan seringkalim menimbulkan miskomunikasi yang pada akhirnya berdampak pada desintegrasi social yang terkadang menimbulkan konflik-konflik dilingkungan social.

\section{KESIMPULAN}

Berdasarkan uraian yang telah dikemukakan pada bab terdahulu, maka bab ini penulis membuat beberapa kesimpulan yang berkaitan dengan analisis mengenai pengaruh politik terhadap kehidupan masyarakat di kampong Yeflio Distrik Mayamuk Kabupaten Sorong bahwa dengan adanya analisis mengenai pengaruh politik terhadap kehidupan masyarakat di kampong Yefliuo Distrik Mayamuk Kabupaten Sorong akan dapat banyak pengetahuan tentang politik sehingga dalam pemilihan selanjutnya tidak terjadi pertikaian dan bisa menerima kekalahan calon kandidat dengan berbesar hati dan yang terpilih pemimpin oleh masyarakat maka harus memenuhi janjijanjinya yang ditawarkan waktu kampaye kepada masyarakat di kampong Yeflio Distrik Mayamuk Kabupaten Sorong dan dapat melakukan pembangunan sesuai program yang direncakan sehingga bisa menyentuh dan terwujud untuk masyarakat dan meningkatkan ekonomi masyarakat.

\section{E. REFERENSI}

1945, U.-U. D. (n.d.). tentang Kedudukan Penyelengara Negara.

Budiarjo, M. (2008). Dasar-Dasar IImu Politik. Jakarta: Pustaka Utama.

Cahyono. (2000). Manajemen. Yogyakarta: Kanisius.
Dwiyanto, A. (1995). Penilaian Kinerja Organisasi Pelayanan Publik. Yogyakarta: Fisipol UGM.
Kartono, K. (1994). Pemimpin dan Kepemimpinan. Jakarta: Raja Grafindo Persada.

Koentjaraningrat. (2002). Beberapa Pokok Antropologi. Jakarta: Lembaga IImu Pengetahuan Indonesia. 
Philipus M. Hadjon. (2012). Penataan Hukum

Administrasi. Surabaya: Fakultas Hukum Unair.

Sedarmayanti. (2007). Reformasi Administrasi Publik, Reformasi Birokrasi, dan Kepemimpinan Masa Depan. Bandung: Refika Aditama.

Soekanto, S. (1993). Sosiologi Suatu Pengantar. Jakarta: Raja Grafindo Persada.

Sugiyono. (2015). Metode Penelitian Kuantitatif, Kualitatif R\&D, Edisi ketujuh. Bandung: Alfabeta.

Tahun, U.-U. N.-U. (2014 ). Tentang Pemerintah Daerah.

Thoha, M. (2002). Perspektif Perilaku Birokrasi : Administrasi Negara Jilid II. Jakarta: Raja Grafindo Persada.

Umar. (2003). Metode Penelitian Kuantitatif di Bidang Pendidikan. Jakarta: Gramedia Pustaka.

Winarno, B. (2017). IImu Sosial dan IImu Politik: Filsafat, Teori dan Meteologi, Paradigma. Jurnal Masalah Sosial, Politik dan Kebijakan, Vol 17 No 1.

Yuningsih, S. S. (2019). Kajian Birokrasi, Departemen Administrasi Publik. Semarang: Press FISIP-UNDIP. 